\title{
FLAXSEED RESPONSE TO N, P, AND K FERTILIZATION IN SOUTH CENTRAL CHILE
}

\author{
Marisol Berti ${ }^{1 *}$, Susana Fischer ${ }^{1}$, Rosemarie Wilckens ${ }^{1}$, and Felicitas Hevia ${ }^{2}$
}

\begin{abstract}
Flaxseed (Linum usitatissimum L.) is a minor crop in Chile. There is interest to increase the number of crops on the current rotation in South Central Chile and also to increase oilseed feedstocks for salmon feed. There is little information published about seed yield and oil content response to $\mathrm{N}, \mathrm{P}$, and $\mathrm{K}$ fertilizers on flaxseed in Chile. The objective of this study was to determine the effect of $\mathrm{N}, \mathrm{P}$, and $\mathrm{K}$ fertilization on flaxseed yield, oil content, and composition. The study was conducted at two locations during two growing seasons (environments), in Chillán 2004-2005, 2005-2006, and in Osorno 2004-2005, 2006-2007. Treatments were four levels of N (0,100, 200, and

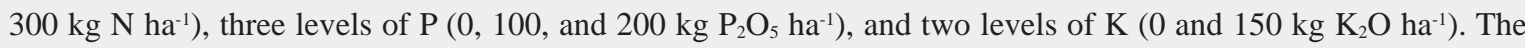
design was a randomized complete block with a factorial arrangement of three factors $(\mathrm{N}, \mathrm{P}$, and $\mathrm{K})$ and four replicates. According to the results, flaxseed yield improved as $\mathrm{N}$ rates increased. Physical optimum rate (rate at which maximum seed yield is obtained) was different depending on the location and year. Nitrogen rate increased oil content and yield up to $200 \mathrm{~kg} \mathrm{~N} \mathrm{ha}^{-1}$. Oil composition was not affected by $\mathrm{N}, \mathrm{P}$, and $\mathrm{K}$ rates, or their interactions. The P and K nutrients did not have an effect on seed yield, oil content, oil yield, and oil composition.
\end{abstract}

Key words: seed yield, oil content, oil composition, $\alpha$-linolenic acid.

\section{INTRODUCTION}

Flaxseed (Linum usitatissimum L.), one of the 100 species in the Linum genus, belongs to the Linaceae family (Hocking et al., 1987), and originates from Europe and Southern Asia (Casa et al., 1999). Flax stems are used for fiber and the seed for oil. Oil has been used primarily to manufacture paint and varnishes (Charlton and Ehrensing, 2001), and to make linoleum floor tiles (Metrycki, 2004).

The world area cultivated with flaxseed is 3016940 ha with an annual average seed yield of $852 \mathrm{~kg} \mathrm{ha}^{-1}$ (FAO, 2007). Canada, India, China, and the USA are the main world producers. Canada and the USA have 93\% of the total exported volume (FAO, 2007). The European Union is the main importer of flaxseed in the world (DIMEAGRO; 2007).

There are only 50 ha of flax cultivated for fiber in Chile and these are found mainly in the Los Lagos Region. Most of the flaxseed and flaxseed oil consumed is imported

\footnotetext{
${ }^{1}$ Universidad de Concepción, Facultad de Agronomía, Av. Vicente Méndez 595, Chillán, Chile.

*Corresponding author (mberti@udec.cl).

${ }^{2}$ Universidad de Concepción, Facultad de Ingeniería Agrícola, Av. Vicente Méndez 595, Casilla 537, Chillán, Chile.

Received: 09 April 2008.

Accepted: 23 May 2008.
}

from Argentina where the cultivated area was 28000 ha in the 2006/2007 growing season (DIMEAGRO, 2007). Chile has increased its flaxseed oil imports in the last two years.

Flaxseed is rich in oil (41\%), protein (20\%), dietary fiber (28\%), contains $7.7 \%$ moisture and $3.3 \%$ ashes (Morris, 2005). It has a high percentage of essential fatty acids, $75 \%$ polyunsaturated fatty acids, 57\% alphalinolenic acid, which is an omega-3 fatty acid, and $16 \%$ linoleic acid, which is an omega-6 fatty acid (Morris, 2005).

Essential fatty acids play a role in cell membrane synthesis by making them flexible (Connor, 2000; Lee and Lip, 2003). They are also precursors for eicosanoids and prostaglandins, a group of metabolites that affect several biological processes such as platelet aggregation, blood clotting, and blood vessel contraction (Simopoulos, 1999; Lee and Lip, 2003). These metabolites play a role in skin regeneration and cholesterol metabolism (Jenkins et al. 1999). Other studies have demonstrated that flaxseed has other molecules that can reduce the risk of cancer, such as secoisolariciresimol diglycoside (SDG) and dietary fiber (Zhou y Blackburn, 1997; Jenkins et al., 1999; Nesbitt et al., 1999; Sauer et al., 2000).

Flaxseed is consumed whole or as flour (Morris, 2005). It can also be included in the ration of laying hens to produce eggs high in omega-3 (Nash et al., 1996), 
chickens (Ajuyah et al., 1993), and pigs (Romans et al., 1995).

Flaxseed is grown as an annual crop and its seed yield is highly related to $\mathrm{N}$ and water availability. $\mathrm{N}$ is the most important nutrient in plant nutrition (Hofman and Cleemput, 2004). It is a component of proteins and chlorophyll needed for plant growth (Lawlor et al., 1998; Lawlor, 2002), and is the most important nutrient in flaxseed production, especially when grown under irrigation (Hocking et al., 1987). Excessive $\mathrm{N}$ fertilization can promote vegetative growth reducing seed production (Franzen, 2004). When water availability is not limited, $\mathrm{N}$ deficiency is the main cause of seed yield reduction (Sánchez and Flores, 1999).

Most reports on the $\mathrm{N}$ response of flaxseed are local and not necessarily related to the general response. Many of the results are also contradictory (Hocking et al., 1997). Diepenbrock and Iwersen (1989) indicated that fertilizing with 40 to $60 \mathrm{~kg} \mathrm{~N} \mathrm{ha}^{-1}$ is enough to reach acceptable seed yields. Hocking et al. (1987) recommended rates from 20 to $60 \mathrm{~kg} \mathrm{~N} \mathrm{ha}^{-1}$, while in Australia reports indicate that maximum seed yield was obtained with $80 \mathrm{~kg} \mathrm{~N}$ $\mathrm{ha}^{-1}$. In the USA and Canada, the recommendation is to fertilize with $90 \mathrm{~kg} \mathrm{~N} \mathrm{ha}^{-1}$ depending on soil fertility (Franzen, 2004). In Argentina, an increase in seed yield was observed from 40 to $120 \mathrm{~kg} \mathrm{~N} \mathrm{ha}^{-1}$ (Sánchez and Flores, 1999). The potential seed yield for flax in the most important producing countries is about half of what is observed in Chile. Therefore, seed yield response to $\mathrm{N}$ is probably much different than the one reported for Canada and the USA.

The objective of this study was to evaluate the effect of $\mathrm{N}$, P, and $\mathrm{K}$ fertilization on seed yield, oil content, oil yield, and oil composition of flaxseed cultivated in South Central Chile.

\section{MATERIALS AND METHODS}

Experiments were conducted during the 2004-2005 and 2005-2006 growing seasons at El Nogal Experimental Station of the Universidad de Concepción, Chillán, Chile (36 $35^{\prime}$ ' S, 72 ${ }^{\circ} 04^{\prime} \mathrm{W}$ and 140 m.a.s.l.), Bío-Bío Region. During the 2004-2005 and 2006-2007 growing seasons, experiments were carried out at the Fundo San Francisco, Osorno ( $40^{\circ} 22^{\prime} \mathrm{S}, 73^{\circ} 04^{\prime} \mathrm{W}$ and 72 m.a.s.l.), Los Lagos Region.

Soil in Chillán is from the Arrayan Series (medial, thermic Humic Haploxerands) with leveled topography and good drainage (Stolpe, 2006). The climate at this location is classified as temperate Mediterranean, with an annual rainfall of $1000 \mathrm{~mm}$ (Del Pozo and Del Canto, 1999). In Osorno, the soil is from the Osorno Series (ashy, mesic Typic Haploxerand). The climate at this location is classified as cold Mediterranean with an annual rainfall of 200 to $1500 \mathrm{~mm}$ (Dirección Meteorológica de Chile, 2008).

The monthly mean temperature and rainfall, chemical and physical soil analysis of each location as well as growing season are described in Table 1.

The experimental design was a randomized complete block with a factorial arrangement with four rates of $\mathrm{N}$ fertilization $\left(0,100,200\right.$, and $\left.300 \mathrm{~kg} \mathrm{~N} \mathrm{ha}^{-1}\right)$, three levels of $\mathrm{P}$ fertilization $\left(0,100\right.$, and $\left.200 \mathrm{~kg} \mathrm{P}_{2} \mathrm{O}_{5} \mathrm{ha}^{-1}\right)$, two rates of $\mathrm{K}$ fertilization ( 0 and $150 \mathrm{~kg} \mathrm{~K}_{2} \mathrm{O} \mathrm{ha}^{-1}$ ), and four replicates. The $\mathrm{N}$ fertilizer was applied as urea, $\mathrm{P}$ was applied as triple superphosphate, and K as KCI. All fertilizers were applied and incorporated at sowing. Seeding dates were 24 August and 9 September for Chillán 2004-2005; 2005 2006, and 22 September and 12 September for Osorno 2004-2005; 2006-2007.

In Chillán, the soil was tilled twice and a rototiller was used to prepare the seeding bed. Trifluralin [2,6-dinitro$\mathrm{N}, \mathrm{N}$-dipropyl-4-(trifluoromethyl)benzenamine] (2 $\left.\mathrm{L} \mathrm{ha}^{-1}\right)$ preplant incorporated was applied 4 days before seeding. At the 4-leaf stage or $10 \mathrm{~cm}$ plant height, MCPA $(0.75$ $\mathrm{L} \mathrm{ha}^{-1}$ ) was applied. The crop was irrigated twice at the end of the growing season. In Osorno, the experiment was conducted in a no-till soil without irrigation. Herbicide, MCPA $\left(0.75 \mathrm{~L} \mathrm{ha}^{-1}\right)$, was applied at the 4-leaf stage for broadleaf weed control.

Seeding rate was $35 \mathrm{~kg} \mathrm{ha}^{-1}$ and the cv. Nekoma (released by North Dakota State University) was used (Hammond et al., 2004). Seed was hand broadcasted into four furrows $5 \mathrm{~m}$ long and spaced $20 \mathrm{~cm}$ apart. Plants were swathed and left in a greenhouse to dry for 4 days before threshing. Swathing and threshing were conducted during the last week of January or the first week of February when $90 \%$ of the capsules were brown.

Seed yield was evaluated using $2 \mathrm{~m}$ from the two center rows of each experimental unit. Biomass samples from plants in each plot were collected at the bud and flowering stages. Then $0.1 \mathrm{~g}$ of dried, ground plant tissue was analyzed by the Kjeldahl procedure to determine total plant $\mathrm{N}$ content (including $\mathrm{N}$ in proteins) in the biomass. The 1000-seed weight was done by counting 1000 seeds in a seed counter and then weighing them. Test weight was determined with a $0.1 \mathrm{~L}$ volume of clean seed from each experimental unit. These last two variables were evaluated only in Chillán 2004-2005; 2005-2006, and in Osorno 2004-2005.

Seed oil content was determined on $40 \mathrm{~mL}$ of clean dried seeds with an NMR (Nuclear Magnetic Resonance Analyzer, Newport 4000, Oxford Institute Limited, Oxford, UK) at the Department of Plant Sciences, North Dakota State University. Oil content was measured on a dry weight basis. This is standard procedure for 
Table 1. Mean monthly temperature, rainfall, and soil analysis of four locations in Chillán 2004-2005; 2005-2006; and Osorno 2004-2005; 2006-2007.

\begin{tabular}{|c|c|c|c|c|}
\hline & \multicolumn{2}{|c|}{ Chillán } & \multicolumn{2}{|c|}{ Osorno } \\
\hline & $2004-2005$ & $2005-2006$ & $2004-2005$ & $2006-2007$ \\
\hline & \multicolumn{3}{|c|}{ Monthly mean temperature $\left({ }^{\circ} \mathrm{C}\right)$} & \\
\hline August & 9.2 & 9.4 & - & - \\
\hline September & 11.2 & 10.5 & 9.1 & 8.9 \\
\hline October & 12.3 & 13.3 & 10.6 & 10.3 \\
\hline November & 15.4 & 16.6 & 13.2 & 12.3 \\
\hline December & 17.9 & 18.3 & 14.7 & 14.7 \\
\hline \multirow[t]{2}{*}{ January } & 19.6 & 20.0 & 15.5 & 16.2 \\
\hline & \multicolumn{4}{|c|}{ Monthly rainfall $(\mathrm{mm})$} \\
\hline August & 87.0 & 250.9 & - & - \\
\hline September & 57.4 & 37.0 & 56.7 & 106.4 \\
\hline October & 83.3 & 19.0 & 26.8 & 144.2 \\
\hline November & 45.0 & 19.3 & 85.1 & 41.9 \\
\hline December & 59.8 & 37.2 & 30.7 & 100.7 \\
\hline \multirow[t]{2}{*}{ January } & 0.0 & 24.9 & 89.2 & 18.9 \\
\hline & \multicolumn{3}{|c|}{ Soil analysis } & \\
\hline $\mathrm{pH}$ & 6.20 & 6.20 & 4.20 & 5.03 \\
\hline Organic matter, \% & 5.20 & 4.60 & 7.60 & 5.79 \\
\hline $\mathrm{N}-\mathrm{NO}_{3}, \mathrm{mg} \mathrm{kg}^{-1}$ & 2.50 & 6.50 & 9.30 & 10.00 \\
\hline P-Olsen, mg kg-1 & 38.00 & 55.30 & 27.70 & 18.70 \\
\hline K available, $\mathrm{mg} \mathrm{kg}^{-1}$ & 448.30 & 419.30 & 200.90 & 262.60 \\
\hline
\end{tabular}

determining oil content of oilseeds (Robertson and Morrison, 1979). Two replicates of each treatment at each location and season were analyzed. The oil yield was obtained multiplying seed yield by oil content.

Gas chromatography (GC) of fatty acid methyl esters (FAME) was performed with a gas chromatographer (Varian 3900) equipped with a flame ionization detector (FID). Analyses were conducted on a CP-WAX 52 CB, 30 $\mathrm{m} \times 0.25 \mathrm{~mm}$ column with an external diameter of $0.39 \mathrm{~mm}$ and $0.25 \mu \mathrm{m}$ filling particle size. Analysis was conducted with set temperatures between 120 and $240{ }^{\circ} \mathrm{C}$ in three stages: $120^{\circ} \mathrm{C}$ for $3 \mathrm{~min}$; increasing temperature by $3{ }^{\circ} \mathrm{C}$ $\mathrm{min}^{-1}$ up to $210^{\circ} \mathrm{C}$ and maintaining that temperature for 55 min; and finally the temperature was increased by $15^{\circ} \mathrm{C}$ $\min ^{-1}$ up to $240{ }^{\circ} \mathrm{C}$ for $65 \mathrm{~min}$. The detector temperature was set at $300{ }^{\circ} \mathrm{C}$, whereas the injector temperature was set at $200{ }^{\circ} \mathrm{C}$ with a flow of $1 \mathrm{~mL} \mathrm{~min}{ }^{-1}$. Standard curves of methyl oleate, methyl linoleate, and methyl linolenate were used to confirm response factors for the GC FID that matched those previously reported by Ackman, 2002.

\section{Statistical analysis}

Statistical analysis was conducted by using standard procedures for a randomized complete block design
(RCBD) with a factorial arrangement (Steel and Torrie, 1980). Nitrogen, P, and K effects were considered fixed for all analyses. Each location-year combination was defined as an 'environment' and was considered a random effect in the statistical analysis. Residual mean squares were compared for homogeneity between environments for each trait. A combined ANOVA was performed on environments found to be homogeneous. Mean separation was performed by applying F-protected LSD comparisons at $\mathrm{P} \leq 0.05$ level of significance. The estimated variance of pairwise mean differences and the corresponding degrees of freedom were calculated to estimate the correct LSD values using SAS System (SAS Institute, 2005). Linear and quadratic regression models were evaluated for each dependent variable and the interactions between them. The regression models and all parameter estimates were significant at $\mathrm{P} \leq 0.05$.

\section{RESULTS AND DISCUSSION}

\section{Seed yield}

ANOVA detected significant differences for the effects of N, N x Environment, N x P x Environment, and $\mathrm{K}$ x P for seed yield (Table 2). Nitrogen fertilization 
Table 2. Sources of variation, degrees of freedom, mean squares, and significance for seed yield, 1000-seed weight, test weight, oil content, and oil yield for four levels of $\mathrm{N}$, three levels of $\mathrm{P}$, two levels of $\mathrm{K}$, and their interactions.

\begin{tabular}{lrrrcrrrr}
\hline Source of variation & df & Seed yield & df & 1000-seed weight & Test weight & df & Oil content & Oil yield \\
\hline Environment & 3 & 40094573 & 2 & 16.84 & 374.4 & 3 & 261.4 & 2653804 \\
Rep (Env) & 12 & 641033 & 8 & 0.07 & 2.7 & 5 & 7.9 & 55259 \\
N & 3 & $13275812 *$ & 3 & $1.09 *$ & 11.7 & 3 & $14.3 *$ & $841264 *$ \\
N x Env & 9 & $1242122 * *$ & 6 & $0.34 *$ & $12.9 * *$ & 9 & $2.7 *$ & $161003 *$ \\
P & 2 & 307710 & 2 & 0.21 & 2.1 & 2 & 1.5 & 1908 \\
P x Env & 6 & 643761 & 4 & 0.20 & 4.2 & 6 & 0.3 & 35371 \\
K & 1 & 681141 & 1 & 0.04 & 0.5 & 1 & 1.4 & 25449 \\
K x Env & 3 & 806134 & 2 & $0.83 * *$ & $12.9 * *$ & 3 & 0.9 & 9725 \\
N x P & 6 & 4129737 & 6 & 0.20 & 1.2 & 6 & $1.3 *$ & 35050 \\
N x P x Env & 18 & $722673 *$ & 12 & $0.30 * *$ & $3.0 * *$ & 18 & 0.5 & 64953 \\
N x K & 3 & 704915 & 3 & 0.45 & 7.1 & 3 & 0.7 & 21855 \\
N x K x Env & 9 & 157955 & 6 & $0.25 *$ & 1.9 & 9 & 0.9 & 13275 \\
K x P & 2 & $415407 * *$ & 2 & 0.21 & 4.8 & 2 & 1.0 & 26780 \\
K x P x Env & 6 & 27753 & 4 & 0.18 & $5.8 *$ & 6 & 0.6 & 33804 \\
N x P x K & 6 & 335125 & 6 & 0.18 & 6.4 & 6 & 0.5 & 10732 \\
N x P x K x Env & 18 & 270631 & 12 & $0.17 *$ & $4.5 *$ & 18 & 0.5 & 56145 \\
Error & 276 & 226877 & 184 & 0.09 & 1.9 & 75 & 0.8 & 51442 \\
CV (\%) & & 22.5 & & 5.12 & 2.1 & & 2.1 & 27 \\
\hline
\end{tabular}

*, **: Significant at $\mathrm{P} \leq 0.05$ and 0.01 . df: degrees of freedom. Env: environment. Rep: replicate. CV: coefficient of variation.

rates increased seed yield with an optimal physical rate variable depending on location and year (Figure 1). The interaction observed with the environments was mainly due to differences in seed yield magnitude. The optimal physical rate for both Chillán and Osorno environments was $222 \mathrm{~kg} \mathrm{~N}^{-1}$ and $291 \mathrm{~kg} \mathrm{~N} \mathrm{ha}^{-1}$, respectively. However, the Chillán environment in 2005-2006 had a much lower seed yield than that obtained at the other environments due to bird damage before harvest, and reducing $\mathrm{N}$ requirements.

The response to $\mathrm{N}$ in this study indicated that $\mathrm{N}$ requirements to optimize seed yield in flaxseed is similar to that of canola grown in Chile. Nitrogen demand of canola in Chile is $5.4 \mathrm{~kg} \mathrm{~N}$ for $100 \mathrm{~kg}$ of seed. A canola seed yield of $4500 \mathrm{~kg} \mathrm{ha}^{-1}$ would require $243 \mathrm{~kg} \mathrm{~N}^{-1}$ (Acevedo, 2003). Other studies indicate that $\mathrm{N}$ uptake in flaxseed is 150 to $200 \mathrm{~kg} \mathrm{~N}^{-1}$ (Hocking et al., 2002), which is similar to the response obtained in this study.

Seed yield increase was $1411 \mathrm{~kg} \mathrm{ha}^{-1}$ comparing the treatment with $300 \mathrm{~kg} \mathrm{~N} \mathrm{ha}^{-1}$ and the control treatment (0 kg N ha-1) in Chillán 2004-2005. This difference was also observed in the analysis of biomass $\mathrm{N}$ content at three different phenological stages. At the bud stage, $\mathrm{N}$ content was $3 \%$ for the control treatment and $4.61 \%$ for the treatment with $300 \mathrm{~kg} \mathrm{~N} \mathrm{ha}^{-1}$. At $50 \%$ flowering, $\mathrm{N}$ content was $1.3 \%$ and $2.39 \%$ for the control and the treatment with $300 \mathrm{~kg} \mathrm{~N} \mathrm{ha}^{-1}$, respectively. In Osorno, the difference in seed yield between the maximum rate applied and the control treatment was only 586 and $660 \mathrm{~kg} \mathrm{ha}^{-1}$ for the 2004-2005 and 2006-2007 growing seasons, respectively. Since $\mathrm{N}$ was entirely applied at seeding, the higher rainfall in Osorno may have leached greater amounts of $\mathrm{NO}_{3}$ from the root zone, thus making it less available for the needs of the crop. Zagal et al. (2003) indicate that $\mathrm{NO}_{3}$ leaching in canola (Brassica napus L.) grown in South Central Chile may reach $20 \mathrm{~kg} \mathrm{~N} \mathrm{ha}^{-1}$ when the rate is split into three applications, and is much greater when it is entirely applied at seeding.

Sánchez and Flores (1999) reported an increase in seed yield with increasing $\mathrm{N}$ rates. However, the optimal physical rate was $107 \mathrm{~kg} \mathrm{~N} \mathrm{ha}^{-1}$, which is much lower than the one obtained in this study for both locations. However, the Sánchez and Flores (1999) study results are from one location and a single season in the province of Buenos Aires, Argentina, with a lower yield potential.

The main effects of $\mathrm{P}$ and $\mathrm{K}$ were not significant, thus indicating that there was no seed yield response to $\mathrm{P}$ or $\mathrm{K}$ fertilization at any of the four tested environments. However, there was a significant response on seed yield for the interaction between $\mathrm{P}$ and $\mathrm{K}(\mathrm{P} \leq 0.05)$ (Table 2). Seed yield increased when $\mathrm{P}$ rates were increased from 0 to $200 \mathrm{~kg} \mathrm{P}_{2} \mathrm{O}_{5}$ ha-1 $^{-1}$, but only when $\mathrm{K}$ was not applied (Figure 2). If the crop was fertilized with $150 \mathrm{~kg} \mathrm{~K}_{2} \mathrm{O} \mathrm{ha-1}$, seed yield increased only from 0 to $100 \mathrm{~kg}_{2} \mathrm{O}_{5}$ ha $^{-1}$ and decreased rapidly with higher $\mathrm{P}$ fertilization rates (Figure 2). Seed yield difference between the control treatment 


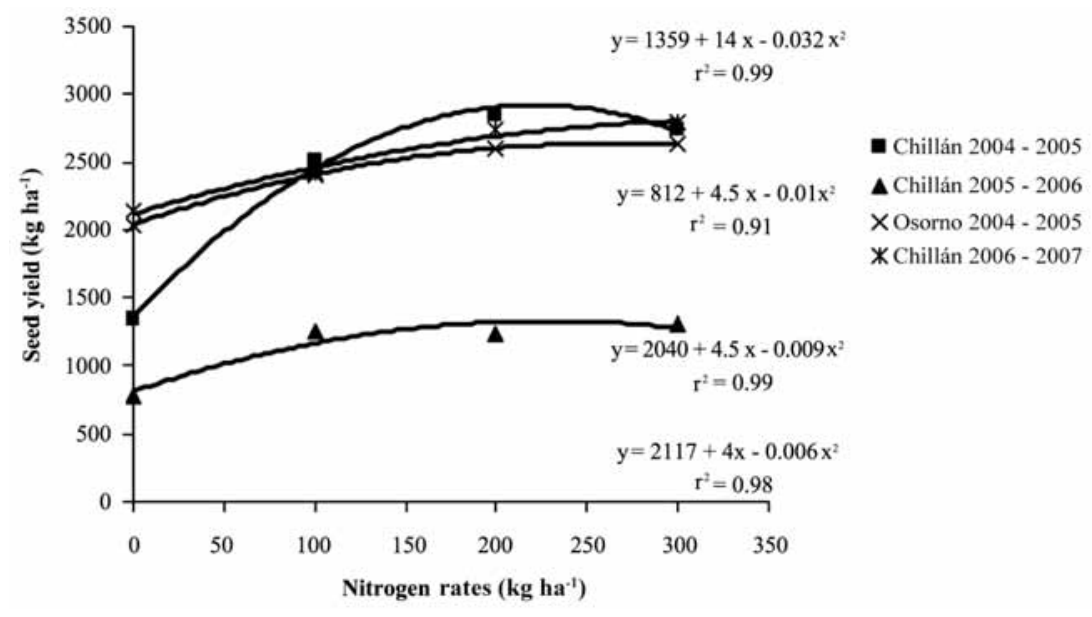

Figure 1. Seed yield response to $\mathbf{N}$ fertilization at four locations. Regression line indicates best fit model to the mean of four environments.

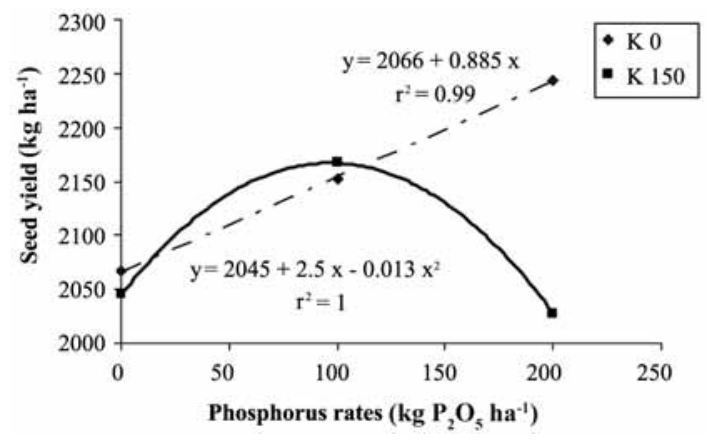

Figure 2. Interaction between $\mathrm{P}$ and $\mathrm{K}$ for flaxseed yield in four environments (Chillán 2004-2005; 2005-2006, and Osorno 2004-2005; 2006-2007). $\mathrm{KO}=0 \mathrm{~kg} \mathrm{~K}_{2} \mathrm{O} \mathrm{ha}^{-1}$ and $\mathrm{K} 150=150 \mathrm{~kg} \mathrm{~K}_{2} \mathrm{O}$ ha $^{-1}$.

( $\left.\mathrm{P}=0 \mathrm{~kg} \mathrm{P}_{2} \mathrm{O}_{5} \mathrm{ha}^{-1}\right)$ and the treatment with $200 \mathrm{~kg}$ $\mathrm{P}_{2} \mathrm{O}_{5}$ ha $^{-1}$ was only $177 \mathrm{~kg} \mathrm{ha}^{-1}$. Given these results, the recommendation for $\mathrm{P}$ fertilizer in flaxseed would be at least $100 \mathrm{~kg} \mathrm{P}_{2} \mathrm{O}_{5}$ ha $^{-1}$ without the addition of $\mathrm{K}$ fertilization in soils with medium or low levels of P-Olsen (8-16 mg $\left.\mathrm{kg}^{-1}\right)$. Experiments were conducted in soils with high POlsen levels (> $16 \mathrm{mg} \mathrm{kg}^{-1}$ ) and $\mathrm{K}$ extractable (200 mg $\mathrm{kg}^{-1}$ ) (Table 1) where a response in seed yield is difficult to obtain. The few existing studies on the response of seed yield with $\mathrm{P}$ and $\mathrm{K}$ have not shown significant responses (Hocking and Pinkerton, 1993; Franzen, 2004).

\section{Seed weight and test weight}

ANOVA detected significant differences for the effects of N, N x Environment, K x Environment, N x P x Environment, and N x K x P x Environment for 1000-seed weight (Table 2). Nitrogen fertilization increased the 1000seed weight between the control treatment and treatments with 100 and $200 \mathrm{~kg} \mathrm{~N} \mathrm{ha}^{-1}$ (Table 3). Significant interaction with the environments was a magnitude of effect because seed weight was greater in the Chillán 2005-2006 and Osorno 2004-2005 environments. Previous studies in flaxseed indicate that 1000 -seed weight is not the yield component most affected by $\mathrm{N}$ deficiency, but the number of capsules and seeds $\mathrm{m}^{-2}$ (Hocking and Pinkerton, 1991; Sánchez and Flores, 1999). Another study indicates that 1000-seed weight increases with $\mathrm{N}$ applications greater than $160 \mathrm{~kg} \mathrm{~N} \mathrm{ha}^{-1}$ (Sánchez and Flores, 1999), while Sarandon et al. (1996), Hocking and Stapper (2001) did not find any differences in seed weight of canola by increasing $\mathrm{N}$ rates.

ANOVA detected significant differences for the effects of $\mathrm{N} x$ Environment, $\mathrm{K}$ x Environment, and $\mathrm{N} x \mathrm{~K}$ $\mathrm{x} P \mathrm{x}$ Environment for test weight (Table 2). Test weight did not increase as $\mathrm{N}$ rates increased. The interactions observed are due mainly to differences in magnitude in the environments. In other words, test weight was higher for fertilization treatments in some of the environments.

\section{Oil content and oil yield}

ANOVA detected significant differences for the effects of N, N x Environment, and $\mathrm{N} \times \mathrm{P}$ for oil content and $\mathrm{N}$ and $\mathrm{N} x$ Environment for oil yield $(\mathrm{P} \leq 0.05)$ (Table 2). Increasing rates of $\mathrm{N}$ decreased oil content (Figure 3 ) from $417 \mathrm{~g} \mathrm{~kg}^{-1}$ to $402 \mathrm{~g} \mathrm{~kg}^{-1}$. A decrease in oil content with high $\mathrm{N}$ rates has been reported before in flaxseed (Dybing, 1965; Hocking, 1995; Hocking et al., 1997) and other oilseed crops such as sunflower (Helianthus annuus (L.) (Steer and Seiler, 1990), and canola (Starner et al., 1999). The reduction in oil content with high $\mathrm{N}$ availability occurs because of a "dilution effect". As N promotes vegetative growth, delaying grain fill and maturity, other 
Table 3. Interaction between $\mathrm{N}$ fertilization and environment for 1000 -seed weight and test weight.

\begin{tabular}{|c|c|c|c|c|}
\hline \multirow[b]{2}{*}{$\mathrm{N}$ rate } & \multicolumn{2}{|c|}{ Chillán } & \multicolumn{2}{|c|}{ Osorno } \\
\hline & $2004-2005$ & $2005-2006$ & $2004-2005$ & Mean \\
\hline $\mathrm{kg} \mathrm{ha}^{-1}$ & \multicolumn{4}{|c|}{ 1000-seed weight (g) } \\
\hline 0 & 5.20 & 5.75 & 6.05 & 5.66 \\
\hline 100 & 5.44 & 6.19 & 6.27 & 5.93 \\
\hline 200 & 5.40 & 6.30 & 6.10 & 5.90 \\
\hline 300 & 5.45 & 6.14 & 6.00 & 5.84 \\
\hline \multirow[t]{2}{*}{ LSD (0.05) N x Env } & & 0.41 & & 0.25 \\
\hline & \multicolumn{4}{|c|}{ - Test weight $\left(\mathrm{kg} \mathrm{hL}^{-1}\right)$} \\
\hline 0 & 69.44 & 66.65 & 65.03 & 67.08 \\
\hline 100 & 68.90 & 67.22 & 66.19 & 67.48 \\
\hline 200 & 69.65 & 68.01 & 66.35 & 67.74 \\
\hline 300 & 70.07 & 68.69 & 64.70 & 68.00 \\
\hline LSD (0.05) N x Env & & 2.53 & & NS \\
\hline
\end{tabular}

Env: environment. NS: not significant.

components such as protein and starch are accumulated in the seed diluting the oil (Hocking and Pinkerton, 1991). The dilution effect is also observed for oil yield (Figure 4). Oil yield increased from 0 to $200 \mathrm{~kg} \mathrm{~N} \mathrm{ha}^{-1}$, decreasing at $300 \mathrm{~kg} \mathrm{~N} \mathrm{ha}^{-1}$. According to the regression model, the rate to optimize oil yield is $217 \mathrm{~kg} \mathrm{~N} \mathrm{ha}^{-1}$.

The interaction between $\mathrm{N}$ and $\mathrm{P}$ indicated that oil yield increased up to $200 \mathrm{~kg} \mathrm{~N} \mathrm{ha}^{-1}$. The response was similar for all levels of $\mathrm{P}$ except when the $\mathrm{N}$ rate was 300 $\mathrm{kg} \mathrm{N} \mathrm{ha}^{-1}$ and no $\mathrm{P}$ was applied, thus decreasing oil yield (Figure 3). This response was similar to that obtained for seed yield. The reduction in oil content and yield at high and low levels of $\mathrm{N}$ and $\mathrm{P}$, respectively can be due to a reduction in the biosynthesis of fatty acids, as a result of lower ATP available for the high energy needs of fatty acid synthesis (Taiz and Zeiger, 2002).

\section{Oil composition}

There was no effect of none of the nutrients and their interactions on oleic, linoleic, and alpha-linolenic acids (Table 4). Dybing (1965) reported a decrease in alphalinolenic acid as $\mathrm{N}$ rates were increased in flaxseed in a greenhouse study with controlled $\mathrm{NO}_{3}$ solutions from 14 to $224 \mathrm{mg} \mathrm{L}^{-1}$.

\section{CONCLUSIONS}

According to the results obtained, $\mathrm{N}$ increased seed yield in all environments. Oil content and oil yield increased up to $200 \mathrm{~kg} \mathrm{~N} \mathrm{Na}^{-1}$. Oil composition was not affected by $\mathrm{N}$ fertilization. Fertilization with $\mathrm{P}$ and $\mathrm{K}$ did not affect seed yield, oil content, oil yield, and oil composition. This response was expected since the experiments were conducted in soils with high levels of both nutrients.

\section{ACKNOWLEDGEMENTS}

Funding for this work was provided by the FONDEF D03-I-1100 project. We thank the technical personnel and Agronomy students who collaborated in the collection of data for this publication: Wilson González, Luis Zañartu P., Eduardo Torres, and Alejandra Villar.

Table 4. Effect of $\mathrm{N}$ rates in flax oil composition. Mean values of three levels of $P\left(0,100\right.$, and $200 \mathrm{~kg} \mathrm{P}_{2} \mathrm{O}_{5}$ $\left.h^{-1}\right)$, two levels of $\mathrm{K}\left(0\right.$ and $\left.150 \mathrm{~kg} \mathrm{~K}_{2} \mathrm{O} \mathrm{ha} \mathrm{h}^{-1}\right)$, and four environments (Chillán 2004-2005; 2005-2006, and Osorno 2004-2005; 2006-2007).

\begin{tabular}{lccc}
\hline $\begin{array}{l}\text { Nitrogen } \\
\text { rate }\end{array}$ & $\begin{array}{c}\text { Oleic } \\
\text { acid }\end{array}$ & $\begin{array}{c}\text { Linoleic } \\
\text { acid }\end{array}$ & $\begin{array}{c}\text { alpha-linolenic } \\
\text { acid }\end{array}$ \\
\cline { 2 - 3 } $\mathrm{N} \mathrm{kg} \mathrm{ha}^{-1}$ & & $\%$ of oil & \\
\cline { 2 - 4 } 0 & 20.01 & 19.78 & 50.82 \\
100 & 19.35 & 20.09 & 51.08 \\
200 & 19.63 & 20.07 & 51.40 \\
300 & 20.00 & 19.78 & 51.98 \\
& $\mathrm{NS}$ & $\mathrm{NS}$ & $\mathrm{NS}$ \\
$\mathrm{CV} \%$ & 17.7 & 23.6 & 3.9 \\
\hline
\end{tabular}

NS: ANOVA did not detect significance for the main effect or interactions. 


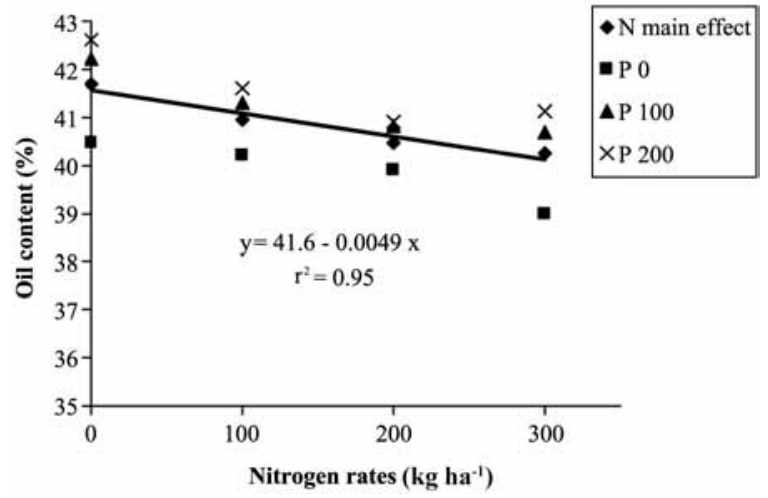

Figure 3. Main effect of $N$ and $N \times P$ interaction for seed oil content. Mean values in four environments. (Chillán 2004-2005; 2005-2006, and Osorno 20042005; 2006-2007). Regression line indicates best fit linear regression model. Levels of $P=0,100$, and 200 kg $\mathbf{P}_{2} \mathrm{O}_{5}$ ha $^{-1}$.

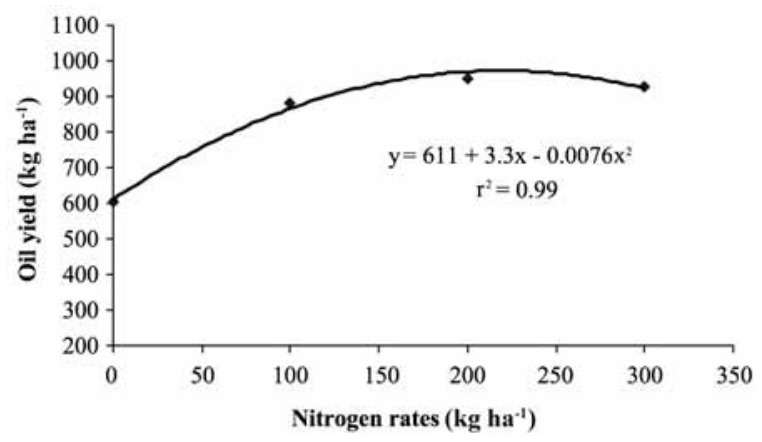

Figure 4. Oil yield response to $\mathbf{N}$ fertilization at four locations. Regression line indicates best fit model to the mean of four environments (Chillán 2004-2005; 2005-2006, and Osorno 2004-2005; 2006-2007).

\section{RESUMEN}

Respuesta a la fertilización N, P y K en lino oleaginoso en la zona centro sur de Chile. El lino oleaginoso (Linum usitatissimum L.) es un cultivo menor en Chile. En la zona centro sur existe interés por ampliar las alternativas para la rotación de cultivos, así como la necesidad de satisfacer la demanda por semillas oleaginosas para la alimentación de salmones. En Chile no hay información relacionada con la respuesta del lino frente a la fertilización. El objetivo del estudio fue evaluar el efecto de $\mathrm{N}, \mathrm{P}$ y K sobre el rendimiento de semillas y contenido de aceite en lino cultivado en dos localidades: Chillán (temporadas 20042005 y 2005-2006) y Osorno (temporadas 2004-2005 y 2006-2007) (ambientes). Los tratamientos fueron cuatro dosis de $\mathrm{N}\left(0,100,200\right.$ y $\left.300 \mathrm{~kg} \mathrm{~N}^{-1}\right)$, tres dosis de $\mathrm{P}$ $\left(0,100\right.$ y $200 \mathrm{~kg} \mathrm{P}_{2} \mathrm{O}_{5}$ ha $\left.^{-1}\right)$ y dos dosis de $\mathrm{K}(0$ y $150 \mathrm{~kg}$ $\mathrm{K}_{2} \mathrm{O}$ ha $\left.^{-1}\right)$. El diseño fue de bloques completos al azar con un arreglo factorial de tres factores (N, P, y K) y cuatro repeticiones. De acuerdo a los resultados, el rendimiento de semillas de lino mejoró a medida que se incrementó la dosis de $\mathrm{N}$, la dosis óptima física (dosis con la cual se obtiene el máximo rendimiento) fue distinta según localidad y temporada. El contenido y rendimiento de aceite aumento hasta $200 \mathrm{~kg} \mathrm{~N} \mathrm{ha-1}$. El N no afectó la composición de los ácidos grasos del aceite. El P y el K no influyeron en el rendimiento de semillas, contenido y rendimiento de aceite, composición del aceite y peso de mil semillas.

Palabras clave: rendimiento de semilla, contenido de aceite, composición de aceite, ácido $\alpha$-linolénico

\section{LITERATURE CITED}

Acevedo, E. 2003. Fertilidad de suelo Available at http:// www.sap.uchile.cl, Universidad de Chile, Santiago. (Accessed October 2008).

Ackman, R.G. 2002. The gas chromatograph in practical analyses of common and uncommon fatty acids for the 21st century. Anal. Chim. Acta 465:175-192.

Ajuyah, A.O., D.U. Ahn, R.T. Hardin, and J.S. Sim. 1993. Dietary antioxidants and storage affect chemical characteristics of $\omega-3$ fatty acid enriched broiler chicken meats. J. Food Sci. 58:43-46.

Casa, R., G. Russell, B. Lo Cascio, and F. Rossini. 1999. Environmental effects on linseed (Linum usitatissimum L.) yield and growth of flax at different stand densities. Eur. J. Agron. 11:267-278.

Charlton, B., and D. Ehrensing. 2001. Fiber and oilseed flax performance. Annual Report. Oregon State University, Corvallis, Oregon, USA.

Connor, E.W. 2000. Importance of n-3 fatty acids in health and disease. Am. J. Clin. Nutr. 71:171-175.

Del Pozo, A., and P. Del Canto. 1999. Áreas agroclimáticas y sistemas productivos en la VII y VIII regiones.116 p. INIA Quilamapu, Chillán, Chile.

Dybing, C.D. 1965. Influence of nitrogen level on flax growth and oil production in varied environments. Crop Sci. 5:491-494.

Diepenbrock, W., and D. Iwersen. 1989. Yield development in linseed (Linum usitatissimum L.). Plant Res. Dev. 30:104-125.

DIMEAGRO. 2007. Perfil del mercado del lino 2006. Gacetilla Informativa del Sector Agroalimentario. Secretaría de Agricultura, Ganadería, Pesca y Alimentos, República Argentina. [On line] Available at http:// www.sagypa.mecon.gov.ar/dimeagro (Accessed January 2008). 
Dirección Meteorológica de Chile. 2008. Osorno. Available at http://www.meteochile.cl/climas/climas_ localidades.html\#osorno (Accessed October 2008).

FAO. 2007. FAOSTAT database. Available at http://www. faostat.fao.org/default.jsp (Accessed February 2008).

Franzen, D. 2004. Fertilizing flax in North Dakota. North Dakota Agricultural Experimental Station, Extension Service SF-717, North Dakota, USA.

Hammond, J.J., J.F. Miller, and J.B. Rasmussen. 2004. Registration of "Nekoma" Flax. Crop Sci. 44:1022.

Hocking, P.J. 1995. Critical nitrate-nitrogen and total nitrogen concentrations for vegetative growth and seed yield of Linola (edible-oil linseed) as affected by plant age. Aust. J. Exp. Agric. 35:239-246.

Hocking, P.J., J.A. Kirkegaard, J.F. Angus, A. Bernardi, and L.M. Mason. 2002. Comparison of canola, indian mustard and linola in two contrasting environments. III. Effects of nitrogen fertilizer on nitrogen uptake by plants and on soil nitrogen extraction. Field Crops Res. 79:153-172.

Hocking, P.J., J.A. Kirkegaard, J.F. Angus, A.H. Gibson, and E.A. Koetz. 1997. Comparison of canola, indian mustard, and linola in two contrasting environments I. Effects of nitrogen fertilizer on dry-matter production, seed yield and seed quality. Field Crops Res. 49:107125.

Hocking, P.J., and A. Pinkerton. 1991. Response of growth and yield components of linseed to the onset or relief of nitrogen stress at several stages of crop development. Field Crops Res. 27:83-102.

Hocking, P.J., and A. Pinkerton. 1993. Phosphorus nutrition of linseed (Linum usitatissimum L.) as affected by nitrogen supply: effects on vegetative development and yield components. Field Crops Res. 32:101-114.

Hocking, P.J., P.J. Randall, and A. Pinkerton. 1987. Mineral nutrition of linseed and fiber flax. Adv. Agron. 41:221-296.

Hocking, P.J., and M. Stapper. 2001. Effects of sowing time and nitrogen fertiliser on canola and wheat, and nitrogen fertiliser on Indian mustard. II. Nitrogen concentrations, $\mathrm{N}$ accumulation, and $\mathrm{N}$ fertiliser use efficiency. Aust. J. Agric. Res. 52:635-644.

Hofman, G., and O. Cleemput. 2004. Soil and plant nitrogen. International Fertilizer Industry Association, Paris, France.

Jenkins, D., C. Kendall, E. Vidgen, S. Agarwal, A. Rao, R. Rosenberg, et al. 1999. Health aspects of partially defatted flaxseed, including effects on serum lipids, oxidative measures, and ex vivo androgen and progestin activity: a controlled crossover trial. Am. J. Clin. Nutr. 69:395-402.
Lawlor, D.W. 2002. Carbon and nitrogen assimilation in relation to yield: mechanisms are the key to understanding production systems. J. Exp. Bot. 53:773-787.

Lawlor, D.W., F.A. Boyle, A.J. Keys, A.C. Kendall, and A.T. Young. 1998. Nitrate nutrition and temperature effects on wheat: a synthesis of plant growth and nitrogen uptake in relation to metabolic and physiological processes. J. Exp. Bot. 39:329-343.

Lee, K.W., and G.Y.H. Lip. 2003. The role of omega-3 fatty acids in the secondary prevention of cardiovascular disease. Q.J. Med. 96:465-480.

Metrycki, B. 2004. Making the flax-linoleum connection. Flax Focus 17(1):4-5.

Morris, D. 2005. Flax - A health and nutrition Primer. Flax Council of Canada. Available at http://www. flaxcouncil.ca/english/ index.php?p=primer\&mp=nut rition (Accessed February 2008).

Nash, D.M., R. Hamilton, K. Sanford, and H. Hulan. 1996. The effect of dietary menhaden meal and storage on the omega-3 fatty acids and sensory attributes of egg yolk in laying hens. Can. J. Anim. Sci. 76(3):377383.

Nesbitt, P.D., Y. Lam, and L. Thompson. 1999. Human metabolism of mammalian lignan precursors in raw and processed flaxseed. Am. J. Clin. Nutr. 69:549555.

Romans, J.R., R.C. Johnson, D.M. Wulf, G.W. Libal, and W.J. Costello. 1995. Effects of ground flaxseed in swine diets on pig performance and on physical and sensory characteristics and omega-3 fatty acid content of pork: I. Dietary level of flaxseed. J. Anim. Sci. 73:1982-1986.

Robertson, J.A., and W.H. Morrison. 1979. Analysis of oil content of sunflower seed by wide-line NMR. J. Am. Oil Chem. Soc. 56(12):961-964.

Sánchez, G.E., and C.C. Flores. 1999. Fertilización nitrogenada en el cultivo del lino oleaginoso (Linum usitatissimum L.). Efectos sobre el rendimiento y sus componentes. Invest. Agr. Prod. Prot. Veg. 14 (3):476481.

Sarandon, S.J., A.M. Chamorro, L.N. Tamango, and R. Bezus. 1996. Respuesta de la colza-canola (Brassica napus L. sp. oleifera forma annua) a la fertilización con $\mathrm{N}$ a la siembra. Efecto sobre la acumulación y partición de la materia seca, el rendimiento y sus componentes. Rev. Fac. Agron. (La Plata) 101(2):179-186.

SAS Institute. 2005. The SAS system for windows. Release 9.1. SAS Institute, Cary, North Carolina, USA.

Sauer, L.A., R.T. Dauchy, and D.E. Blask. 2000. Mechanism for the antitumor and anticachectic effects of n-3 fatty acids. Cancer Res. 60:5289-5295. 
Simopoulos, A.P. 1999. Essential fatty acids in health and chronic disease. Am. J. Clin. Nutr. 70:560-569.

Starner, D.E., A.A. Hamama, and L. Bhardwaj. 1999. Canola oil yield and quality as affected by production practices in Virginia. p. 254-256. In J. Janick (ed.) Perspectives on new crops and new uses. ASHS Press, Alexandria, Virginia, USA.

Steel, R.G.D., and J.H. Torrie. 1980. Principles and procedures of statistics: A biometrical approach. $2^{\text {nd }}$ ed. McGraw-Hill, New York, USA.

Steer, B.T., and G.J. Seiler. 1990. Changes in fatty acid composition of sunflower (Helianthus annuus L.) seeds in response to time of nitrogen application, supply rates and defoliation. J. Sci. Food Agric. 51:11-26.

Stolpe, N.B. 2006. Descripciones de los principales suelos de la VIII Región de Chile. 84 p. Universidad de Concepción, Departamento de Suelos y Recursos Naturales, Chillán, Chile.
Taiz, L., and E. Zeiger. 2002. Plant physiology. $3^{\text {rd }}$ ed. 690 p. Sinauer Associates Publishers, Sunderland, Massachussets, USA.

Zagal, E., J. Hirzel, and I. Vidal. 2003. Evaluación de la recomendación de fertilización nitrogenada para cultivos anuales en suelos de origen volcánico usando un modelo de simulación. Agric. Téc. (Chile) 63:94104.

Zhou, J.R., and G.L. Blackburn. 1997. Bridging animal and human studies: What are the missing segments in dietary fat and prostate cancer? Am. J. Clin. Nutr. 66:1572-1580. 